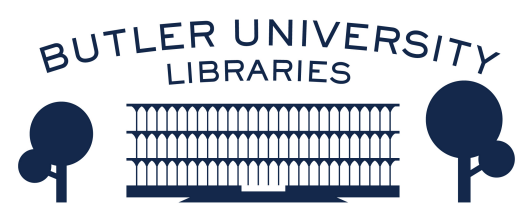

Journal of Hindu-Christian Studies

Volume 10

Article 7

January 1997

\title{
Vendanta and Modern Science: Some Demarcation Criteria and Commonalities
}

Varadaraja V. Raman

Follow this and additional works at: https://digitalcommons.butler.edu/jhcs

Part of the Religion Commons

\section{Recommended Citation}

Raman, Varadaraja V. (1997) "Vendanta and Modern Science: Some Demarcation Criteria and Commonalities," Journal of Hindu-Christian Studies: Vol. 10, Article 7.

Available at: https://doi.org/10.7825/2164-6279.1153

The Journal of Hindu-Christian Studies is a publication of the Society for Hindu-Christian Studies. The digital version is made available by Digital Commons @ Butler University. For questions about the Journal or the Society, please contact cbauman@butler.edu. For more information about Digital Commons @ Butler University, please contact digitalscholarship@butler.edu. 


\title{
Vedānta and Modern Science: Some Demarcation Criteria and Commonalities
}

\author{
Varadaraja V. Raman \\ Rochester Institute of Technology
}

\begin{abstract}
Historical background
In the past centuries, Western scholars who studied the complexities of Indian thought had at least two motivations. First, there was a need to understand the alien mind-set which they were eager to ameliorate (convert), for they worked on the conviction that they were bringing truth, light, and salvation to a misguided lot. They felt that it was their evangelical responsibility to redeem lost souls. ${ }^{1}$ Some of them, whether overtly or subtly, wanted to give moral ammunition to the colonial governments which were summarily imposing Western values and worldviews on the subject peoples. 2
\end{abstract}

The second motivation for European efforts to understand Eastern traditions was purely intellectual, inspired by the outlook of European Enlightenment. Following the scientific revolution, a whole new tradition of scholarship emerged in the West: that of exploring and understanding every aspect and expression of the human spirit, no matter what or where in the world. So arose the search for the historical Jesus, the effort to decipher the hieroglyphics, the desire to unearth lost civilizations through archaeological excavations, the probings into the wisdom of ancient Greek thinkers, and the efforts to translate literary and philosophical works from every language into the major European languages. ${ }^{3}$ The overall effect of such an historical/academic quest has been to enrich the human spirit, culturally, intellectually, and spiritually.

However, the effect of the Enlightenment was very different on Western and on
non-Western intellectuals. In the West, an awakening gradually arose to the effect that the intrinsic superiority one had assumed vis-à-vis non-Western cultures by virtue of military conquests was largely illusory. As Western thinkers were exposed to myriad modes beyond their own of considering life's experiences, they began to see the narrowness in their earlier appraisals of other cultures and civilizations.

European attempts to unravel the structure and past of non-Western cultures have had a different sort of impact on the non-Western world. On the one hand, a good deal of long forgotten and mythologized history was brought back to rational light, and one began to get a better appreciation of one's own past. On the other hand, contrary to what happened within the Western matrix, there developed in the nonWestern world an ethnic self-awareness in a global context whose effect was to assert one's own uniqueness - even superiority in the face of arrogant Western intruders. ${ }^{4}$

A little over a hundred years ago, Swami Vivekananda recast the essence of ancient Hindu insights in a language intelligible to the average educated person in the Western world. He did this with such enthusiasm and eloquence that he had spellbound audiences wherever he spoke. ${ }^{5}$ At the same time, more scholars and intellectuals in the Western world became aware of the deep insights and profound wisdom implicit in the Hindu worldview.

However, the fact remained that while Europe could boast of its positive sciences and practical technologies, Hindus could 
only expound on subtle metaphysics and Yogic powers. So, already in the nineteenth century, a defensive reaction was provoked in some Indians vis-à-vis the technological innovations of the colonizing oppressors. One expression of this was to assert that India too had these [modern science and technology] and more, at one time. An eminent propagator of this notion was Swami Dayanand Saraswati who injected considerable pride and self-dignity in the hearts of his people. ${ }^{6}$ A statement of that point of view may be found in the following paragraph which appeared in a popular magazine in 1906:

Western science has brought telegraph, railways and small industry. The westerners think that they have made a unique contribution in above areas. If somebody reads Sürya Siddhanta they would be able to find how the qualities and usages of steam had been known to Hindus. Half-baked English-educated Indians make some noise without realizing what they have in Hindu tradition. Ancient Indians knew about space, telescopes, watches, chemical warfare, and also travelled in air. Now all that is gone. ${ }^{7}$

In the meanwhile, largely via the school and university systems which used English as the primary medium of instruction, the methods and discoveries of modern scientific ideas and research modes permeated the Indian scene. Given that India has always had a rich intellectual tradition with great reverence for knowledge and inquiry, many Hindu minds resonated with the incoming scientific methodologies. Before long, significant contributions to modern science came from Indian scientists too. ${ }^{8}$

During the first third of the twentieth century, while science advanced along undreamed of directions and serious scholarly studies of Upanișadic and Vedāntic literatures were undertaken, some thinkers began to discover remarkable parallels between the findings of science and the propositions of ancient Hindu thinkers.
Some of their assertions are interesting and provocative, and some questionable and naive, at least from a technical-science perspective.

Thus, for example, in a conference on Vedic Science held in Europe a decade ago, it was proclaimed that the "Three-in-One Maharishi Technology of the Unified Field" was the same as the Unified Field Theories of current physics, and that the former "had been validated" in several studies in such diverse disciplines as "physiology, psychology, sociology, and ecology..."9

Similarly, we read in a book published not so long ago that "the observations (of ancient Indian physicists) tally with those of modern cosmogonists on ... the origin of the Sun, its structure and fuel etc...." and that "both the views, ancient and modern, are similar; based on identical grounds and arriving at the same conclusion." 10

Again, by an ingenious interpretation of the word samskāra, one scholar has suggested that in Buddhist thought, things were regarded as events, which happens to be a fruitful term in twentieth-century physics. ${ }^{11}$ This inspired another writer to assert in the context of discussing the highly technical S-matrix theory of current physics, that "What Buddhists have realized through their mystical experience has now been rediscovered through the experiments and mathematical theories of modern science." 12

It must be noted that the seeds for such interpretations were sown by some wellmeaning Western scholars, already in the early part of this century. Thus, in $1921 \mathrm{Sir}$ John Woodroffe asserted that Vedāntic thought "is in conformity with the most advanced scientific and philosophical thought of the West...".13 However, most Indian physicists in the first half of the twentieth century argued against such facile claims. Preeminent among them was the astrophysicist Meghnad Saha. Some of his more orthodox contemporaries attacked him in severe terms for his views. ${ }^{14}$

This historical setting has played an often unrecognized role in many current 
discussions on science and Hindu philosophy, as indeed on science and other non-Western cultures more generally. For a more objective appreciation of science and the classical Hindu philosophical/theological worldview, one needs to transcend the framework of the colonial straight-jacket which prompts claims to the effect that the results and insights of modern ("Western") science are implicit in Sanskrit aphorisms. Rather, the value and significance of Vedantic worldviews lie elsewhere.

\section{The Spirit of Inquiry: Science and Vedānta}

The parallels between Vedānta and science are to be sought, not in the details of the results of the enterprises, but in their goals.

The undeniable identity between Vedānta and science lies in the spirit of inquiry. The greatest minds of the ages have striven to explain the wonders of nature and the universe. Why does the sun rise and set, how do stars shine, what makes the rainbow, and what causes rain? Then there are even greater puzzles that need to be solved: when did the universe begin and how? is there an end to space and time? And finally, there is the mystery of mysteries: human consciousness. Even if there is a physical reality beyond human consciousness, is the perception of that reality modified by the constraints of human consciousness or enhanced by its capacity?

These are penetrating questions. Inquiring minds have posed them in all cultures and at all times, but they have followed different methodologies at different times. The goal of science, as Karl Pearson expressed succinctly in The Grammar of Science, is nothing less than the complete interpretation of the whole universe. The Brahma Sütra opens with the bold phrase:

atāto brahma-jijñäsā

Therefore, then, the wish to explore

Ultimate Reality.

Thus, both science and Vedānta seek to uncover the nature of Ultimate Reality. This
Ultimate Reality is referred to as Brahman in Vedāntic terminology. It is in this respect, i.e. in the matter of the goal of the enterprise, that Vedānta and science are the same. But there are essential differences between the two in the methodology followed, in the basic assumptions, and in the nature of the results obtained. These distinctions are seldom explicitly enunciated in discussions of Vedānta and science.

\section{Relevance and Significance of Vedānta} Unlike doctrines of other religious systems, Vedānta is not simply based on the sacredness of this book or that. The Vedāntic vision is not mere philosophy or metaphysics. Rather, it is the formulation of a worldview arising from a unique mode of exploration. More importantly, it is a discovery derived from a mode of inquiry very different from the standard (currently followed) scientific mode.

The essential thesis (or discovery) of Vedānta is that there is something beyond our perceptually acquired impressions. Just as physical instruments like the telescope and the microscope make us aware of hidden aspects of physical reality, Vedāntic vision brings to our cognition a different realm or dimension of the universe. This dimension transcends space, time, and causality. The recognition that there is a transcendent Reality beyond the purely perceptual gives us a very different and much deeper vision of the ultimate nature of the universe.

This discovery is significant and relevant for at least three reasons:

(a) This recognition enables us to regard the human experience in richer ways. Our attitudes and behaviours in life are governed by the meaning and purpose we attach to things. Vedāntic revelation gives us a perspective from which life takes on a different significance. The affirmation and acceptance of trans-physical reality is part of any religious experience. Such a framework has the potential for providing one with a positive frame of mind, and for enriching human life with hope and purpose. Prayer 
and meditation are efforts to communicate with and experience the transcendent dimension of Reality.

(b) Vedāntic recognition underscores the relative nature of the intellectual-rational mode of grasping the ultimate nature of the world. It reminds us that the intellectualrational mode enables us to become aware of only one dimension of Reality: its phenomenal component. Vedāntic awareness enables one to see that while the logical mode is useful and essential in the comprehension of this dimension, there is another dimension of Reality which is no less significant. Without disparaging the logical-empirical modes of grasping the phenomenal world, one may still appreciate its scope and limitations. 15

(c) Finally, the Vedāntic system exposes the complexity of the neural network of the human brain which we normally tend to look upon as an instrument for handling only the physical dimensions of the world. Vedāntic revelation uncovers the spiritual potential of the brain, which is a subtler region in the spectrum of human capacities. It is this spiritual component that enables the practitioner to attain states of transcendental awareness. ${ }^{16}$

Whether this spiritual component is superimposed on the material elements constituting the brain, even as an image is reflected in a bowl of clear water, or it is an as yet unexplained consequence of the structure of biochemical molecules, we are unable to affirm at this point. From the first perspective, if we make an analogy between the human brain and the telescope, say, then ordinarily the lenses of the instrument are blurred and foggy. Meditation (and other spiritual exercises) would be equivalent to cleaning and polishing the eye-piece. This enables us to see more, and more clearly, aspects that are otherwise either blurred or not visible at all. According to the second perspective, the chemistry of the human brain concocts many impressions of which transcendent reality may be one.

\section{The Nature of Scientific Inquiry and of its Results}

(a) The framework of inquiry in the scientific mode is essentially intellectual. Science is connected intimately to the rational dimension of the human brain. That is why logical consistency and reference systems play fundamental roles in science. But there are aspects of human life that are not amenable to strict logic, such as beauty and a sense of justice. These are beyond the grasp of scientific analysis.

(b) All science is based on our sensory perceptions. Recognizing the limitations of these perceptions in sensitivity and range, science devises instruments to enhance and extend them. Science relies heavily on instrument-based experiments. Scientific experiments involve systematic and purposeful interactions with specific aspects. of the external world, consciously making every effort to minimize and eliminate when possible any interference of the human observer with what is being observed. This is how science has revealed microbes and galaxies, the satellites of Jupiter and the motion of molecules, ultrasound and microwaves: aspects of the physical world which are utterly unrecognizable by our normal sensory faculties. And yet, science is only concerned with (directly or indirectly) sensorially perceived reality. It does not and cannot say anything about what is not perceptually recognizable. If there are modes of perception beyond the cerebral and the sensory, such as the intuitional or the revelatory, they would, by definition, elude scientific analysis.

(c) At its more advanced levels, aside from complex instruments like radio telescopes and high-energy accelerators, the electron microscope and computers, science utilizes very abstract concepts, and highly sophisticated mathematics. Indeed, at certain levels of science, concepts and consistency alone, in so far as they seem to map the external world, make sense. Visualizable descriptions of Reality become an impossibility. ${ }^{17}$ 
(d) The myriad aspects of physical Reality beyond the cognition of everyday experience which have been exposed by science have come about by elaborate and repeated procedures conducted by thousands of individuals at various times and places. Science does not and cannot give intensely personal and non-transferable visions of the world. Indeed, the scientific establishment rejects such impressions, not because they may be false, but because standard scientific methodology does not know of any way of coping with (evaluating) them.

(e) Science is a collective enterprise. Its findings arise from the gropings and efforts of countless individuals who rely on the results of fellow scientists, often communicating with one another. No scientific result of significance has arisen from the efforts of an individual with no contact or interaction with the work of others.

(f) Science is self-corrective as an enterprise. In other words, the findings of scientists are subjected to severe critiques from fellow scientists, and in the process scientific understanding is fine-tuned, modified, improved upon, and sometimes discarded to give place to newer and better results.

(g) The goal of science is to explain and understand the phenomenal world, not simply to become aware of it. If a proposition does not lead to the explanation of a specific observed aspect of the phenomenal world, it is of little interest to the scientific worldview. ${ }^{18}$

(h) Scientific results are fruitful from a practical point of view. What this means is that the findings of science may be put to use to ameliorate the human condition on the material plane, though this may not be a guarantee of their intrinsic correctness. However, the results and visions of science are generally incapable of adding to our moral or spiritual dimensions.

\section{Vedānta}

It must be clear from what has been stated above that Vedānta is very different from science as the term is understood by the practitioners of science. More specifically:

(a) Vedāntic revelation is not the result of collective activity, although it could be corroborative.

(b) Spiritual inquiry is not self-corrective in that the articulated aphorisms as to the nature of Brahman are not revised and reformulated by mystics for public debate and discussion, although non-mystics may and do interpret and comment upon the declarations of the seers.

(c) Vedāntic revelations do not arise from intellectual modes of activity, even if the seers sometimes attempt to express them in intellectual terms. In such instances, the rssis have often insisted upon the constraints and limitations of the logical mode in the recognition of transcendent dimensions of Reality. For those who have not had the revelation, the śästras are said to provide the basis of proof. ${ }^{19}$

(d) Vedānta does not attempt to describe the world, but to reveal its inner essence. It is based on anubhava which is intensely personal, and it does not call for experiments which demand external tools and meters.

(e) Vedānta does not inquire into the particular details of the phenomenal world. Rather, it reveals the nature of the substratum of the universe in its totality.

(f) Vedāntic revelations are not fruitful in the sense in which scientific results are fruitful. They do not enable us to predict the evolution of particular phenomena such as where a ballistic missile will land, or when the next comet will appear, nor can they find a cure for malaria or invent a computer.

(g) Vedānta is concerned with the unchangeable underlying principle of the universe whereas science analyses every detail of all that is changing and ephemeral, and the unchanging quantitative features in the phenomenal, world. Thus, Vedānta explores what is permanent and eternal, the principle that does not change, rather than the measurable quantities that do change. 
Indeed Śaṅkara defines Reality as that which is not subject to any change:

\section{satyititi yad-rūpena yanniścitām}

tad-rūpam na vya-bhi-carati tat-satyam.

This is the Reality with which Vedānta is concerned, while science is primarily interested in the specific ways in which unchanging principles give rise to the changing aspects of the perceived universe. ${ }^{20}$

(h) Vedānta is revelatory of a reality beyond the physical world of sensory perceptions. As mentioned earlier, it unveils a dimension of Reality that transcends spatial-temporal and causal categorizations. By its very nature, this dimension of reality is not something that can be conceptually grasped, logically analysed, or verbally articulated. The Upanișadic seers had clearly recognized differences between sensory perception, logical analysis, and intuitive apprehension. Transcendent Reality can be grasped only in its totality by the human spirit, not in its piece-meal subdivisions. The fundamental thesis of Vedānta is that transcendent Reality can be apprehended, not comprehended; experienced, not experimented with.

\section{Where the Twain do Meet}

While recognizing the important differences between (current) science and Vedānta, we may still note the following points of contact between the two enterprises.

(a) The goal of classical science was descriptive and explanatory of the world in so far as it is independent of human presence in it. The obsession of (classical) science is with objectivity. Science seeks to know how the world would function whether or not the human mind happens to be in it. In the terminology of Vedānta, science is an attempt to picture prakrti without a purusa, even if this were as wasteful and irrelevant as encyclopedias buried in the bottom of the sea.

One objection to this goal of science is that this goal is impossible to reach in principle, since science is based on concepts which are products of the human mind. What one means by scientific objectivity, then, is that scientific analyses and descriptions ought to be independent of the specific human minds which articulate or accept them. In other words, scientific theses demand certain universality of appeal based on appropriate experimentation and logical modes. Scientific objectivity is essentially collective subjectivity. Vedānta grants such collective subjectivity, but regards it as illusory.

The second and more serious difficulty with objectivity has arisen from our exploration of the microcosm. Quantum physics has brought out the intrinsic inseparability between subject and object, between the observed and the observer. A solution to this impasse may be found by accepting levels of reality: a macroscopic level at which a bifurcation between subject and object is not only possible, but indispensable for a coherent description of the world; and the microcosmic level where such a distinction becomes not only impossible in practice, but also untenable conceptually. This would conform to the Vedāntic doctrine that the nature of reality is a function of the level at which one apprehends it.

(b) The interconnectedness between the conscious mind (purusa) and the inert world (prakrti) makes separateness (objectivity) very difficult to hold. Indeed it forces us to look upon the physical reality as being ultimately a single unified whole. ${ }^{21}$ Moreover, the separateness that we observe and experience is a consequence of the level at which we normally function. From this perspective it is not impossible to see how, exploring the world at a different level of experience, the wholeness may become more apparent. The substratum of physical reality may be grasped either analytically (i.e. via the scientific mode) through concepts, mathematics, and instruments: leading to quantitative and exploitable results; or through the mystical mode (meditation, 
yogic exercises, etc.): leading to intensely personal and profound experiences.

(c) Finally, the notion of spatio-temporal and causal transcendence, which does not make any sense in classical physics, has gained some respectability in discussions on black holes and pre-big-bang cosmology. In recent decades serious physicists and cosmologists have been freely talking about conditions under which the traditional notions of space and time and physical laws break down. 22

\section{The Mind-Body Dichotomy}

Existence for short or long periods can occur without feeling or thinking, without experience of any kind. Stones, mountains, and stars, for example, exist for eons without (to all appearances) experiencing anything, let alone thinking or inquiring. On the other hand, biological entities, at least in their more evolved forms, have experiences which result primarily from built-in neural networks. They cause positive and negative impacts which may simply be called pleasure and pain on the experiencing system. In the more sophisticated forms of biological entities, in what is customarily regarded as the pinnacle of evolution, the cerebral networks include certain additional components which lead to what we refer to as the logical mode of thought.

It is important to recognize that the logical mode is not necessary for biological survival, much less for mere existence. From the most minute microbes to mammals of impressive sizes and complexities, there are ample instances of highly successful creatures which do not, or at least do not seem to, display the slightest capacity for logical thinking or interest in mathematical reasoning.

The intangible manifestation of the logical component of the brain is referred to as the mind. The mind is what causes us to wonder about the nature of the physical world. It is the mind that prompts us to explain and try to understand the world of experience. Since time immemorial, philosophers have reflected upon these two principal aspects of human existence: body and mind.

But, in addition to the mental, the human brain generates another, no less significant, dimension, namely the spiritual. Our failure to recognize the spiritual dimension as an independent and fundamental feature of the human brain is largely responsible for much of the conflict and confusion in discussions on science and religion.

There are many matters of import and interest to human beings that are not science. Some of these may even resist syllogistic formulations. These matters do not pertain to the functioning of the physical world, but rather to the experiential dimension of human consciousness. In so far as they go beyond normal logical analysis, and are significant to the human experience, they may be described as trans-rational. Common instances of trans-rational aspects of human life are relationships and associated feelings such as friendship, kindness, and love.

Because of the power and prestige that the scientific mode has acquired, there is often an eagerness to find scientific support for trans-rational matters also. It is futile and irrelevant to look for scientific buttressing for them. Like music and art, their intrinsic value and import are independent of scientific proof and justification. Vedāntic vision belongs to the trans-rational category.

Spiritual yearning may be defined as the capacity of the human brain which generates a longing for and a perception of, connections with the world at large. It is an important example of the trans-rational dimension of human consciousness. Like thirst and hunger, and even more than a need for logical consistency, the spiritual dimension appears to be essential for normal and healthy human life.

Viewed thus, rather than as an unveiler of aspects of physical reality, Vedāntic insights become valuable and relevant expressions of the human spirit. Vedānta is 
not prescient science, but an enormously enriching trans-science.

Being religious is another engagement in an important non-science activity. Expressions of or conclusions from religious experiences, whether in the scriptures or in autobiographies of mystics, may be very interesting, but they do not and cannot constitute science because they do not include the characteristics of science considered above.

Except for professors of religion and authors of scholarly papers and popular books, religion is not an intellectual activity. The truly spiritual masters have always recognized this. That is why the great mystics, whether Śankara in the Hindu tradition, the sufis in the Islamic, or Saint Thomas in the Christian, have consistently devalued the intellect as an instrument for grasping a different realm of reality.

Like art, music, literature, religion answers to some of our most fundamental needs and, like other non-sciences, it can enrich the human experience. Non-science is not a pejorative term. Rather it is a classificatory criterion. Because religion once played the role of science also (in trying to explain the world), and because science has usurped this role, there is sometimes an urge, at the very least, to make it an ally of science, rather than recognize it as an enterprise in its own right.

\section{Notes}

1. William Carey was a pioneer in this mindset. His work, An Enquiry into the Obligations of Christians to use Means for the Conversion of the Heathens (1792) expounds the evangelical point of view.

2. In recent years this side of European scholarship has been emphasized, and men like Max Müller and Monier-Williams are receiving some beating for what has been interpreted by some as their hidden agenda.

3. This motivation for orientalist (and other) scholarship in the 18th and 19th centuries is underplayed or ignored in post-modern writings on history.

4. Indeed, one of the goals of history writing in our own times is to foster ethnic pride and establish priority in scientific discoveries and insights by non-Western peoples.

5. Reporting on one of Vivekananda's lectures the New York Herald said, "After hearing him we feel how foolish it is to send missionaries to this learned nation...", quoted in $\mathrm{K}$. C. Vyas, The Social Renaissance of India, 1957, p. 102.

6. According to Dayanand Saraswati, the material expressions of the industrial revolution as well as the scientific discovery of a heliocentric solar system were all implicit in the Vedas.

7. P. N. Chokkalingam, "Science and Technology in Ancient India", Vivek Bhanu, Aug-Sept. 1906, pp. 313-9, quoted in Deepak Kumar, Science and the Raj, 1995.

8. It is significant that within the first three decades of the 20th century, at least half a dozen Indian scientists gained international reputations and left permanent marks by their solid contributions.

9. First European Conference on Vedic Science, Report No. 1, Maharishi Vedic University (1985).

10. Babu Ram Yadava, Vedic Cosmogony, Vijñāna Prakaśana, Aligarh, 1987, p. 148.

11. D. T. Suzuki, The Essence of Buddhism, p. 55.

12. Fritjof Capra, Tao of Physics, p.270.

13. Sir John Woodroffe, The World as Power, 1921. It should be pointed out that the essence of the Brahma Sütra has been subjected to various interpretations, which makes claims to the effect that science and Vedānta say the same thing no more meaningful than that science and religion say the same thing, for which interpretation of Vedānta (or which religion) does one have in mind?

14. For more on this, see Debiprasad Chattopadhyaya, History of Science and Technology in Ancient India, Vol. I, 1986, Ch. I.

15. The phenomenal world and the Absolute are complementary in the quantum-mechanical connotation of the term: when one is in the recognition mode of one, the other is beyond one's grasp.

16. From the Vedāntic perspective we can never 
know this by logical-scientific means: it would be like the eye seeing itself. But it is the spiritual capacity of the human brain (or consciousness) that enables us to become aware of the substratum undergirding the ephemeral phenomenal panorama.

17. In the description of the microcosm in the language of quantum physics (and no other language is available), many conceptual elements arise (such as parity, exchange operator, and isotopic spin) which are indispensable and enormously fruitful in the physics of fundamental phenomena, but which defy any concrete and tangible description.

18. The notion of scientific explanation is a complex philosophical issue. Suffice it to say that at the minimum logical consistency, causal links, and verifiable consequences are involved in any scientific explanation.

19. Brahma Sūtra III.3.

20. The unchanging quantitative principles in the physical universe are the so-called conserved quantities of physics: matter energy, electric charge, baryon number, lepton number, etc.

21. This is the starting point of speculations on the nature of reality by some modern physicists, in particular, David Bohm in his Foundations of Physics, I, 1971.

22. In the so-called regions of naked singularity (emerging from the work of Stephen Hawking and Roger Penrose) within a black hole, all the laws of physics collapse. 